\title{
KEEFEKTIFAN MODEL PEMBELAJARAN BRAIN BASED LEARNING TERHADAP HIGH ORDER THINKING SKILLS (HOTS) MAHASISWA PGSD UNIPA SURABAYA
}

\author{
Via Yustitia ${ }^{1}$, Triman Juniarso ${ }^{2}$ \\ ${ }^{1,2}$ Universitas PGRI Adi Buana Surabaya \\ via.yustitia@unipasby.ac.id ${ }^{1}$, triman@unipasby.ac.id ${ }^{2}$
}

\begin{abstract}
ABSTRAK
Tujuan dalam penelitian ini adalah untuk mengetahui keefektifan model pembelajaran Brain Based Learning (BBL) terhadap High Order Thinking Skills Mahasiswa PGSD pada Mata Kuliah Konsep Matematika Lanjut. Populasi dalam penelitian ini adalah mahasiswa PGSD Adi Buana Surabaya angkatan 2017. Teknik sampling yang digunakan adalah simple random sampling, diperoleh dua kelas sampel yaitu kelas 2017 A sebagai kelas eksperimen dan kelas 2017 B sebagai kelas kontrol. Pengumpulan data dilakukan dengan metode dokumentasi, tes, observasi, dan angket. Analisis data menggunakan uji ketuntasan belajar (uji t dan uji proporsi) dan uji kesamaan rata-rata. Berdasarkan hasil penelitian menunjukkan bahwa kelas eksperimen telah mencapai ketuntasan belajar. Hasil uji kesamaan rata-ratamenunjukkan bahwa rata-rata HOTS mahasiswa kelas eksperimen lebih baik dari pada kelas kontrol. Berdasarkan hasil penelitian dapat disimpulkan bahwa model pembelajaran BBL efektif terhadap HOTS mahasiswa PGSD pada mata kuliah Konsep Matematika Lanjut.
\end{abstract}

Kata kunci: brain based learning, high order thinking skills, matematika

\section{ABSTRACT}

The purpose of this study was to determine the effectiveness of the Brain Based Learning (BBL) learning model on High Order Thinking Skills of PGSD Students in Konsep Matematika Lanjut Courses. The population in this study was the 2017 students of the Adi Buana PGSD Surabaya class. The sampling technique used was simple random sampling, obtained two sample classes namely 2017 A class as the experimental class and 2017 B class as the control class. Data collection is done by the method of documentation, tests, observations, and questionnaires. Data analysis using learning completeness test ( $\mathrm{t}$ test and proportion test) and average similarity test. Based on the results of the study showed that the experimental class had achieved mastery learning. The average similarity test results show that the average HOTS of the experimental class students is better than the control class. Based on the results of the study it can be concluded that the BBL learning model is effective against HOTS PGSD students in the subject of Konsep Matematika Lanjut.

Keywords: brain based learning, high order thinking skills, mathematics

\section{PENDAHULUAN}

Pendidikan merupakan bagian integral pembangunan dan kemajuan suatu bangsa. Kualitas pendidikan di Indonesia cukup memprihatinkan. Hal ini ditunjukkan oleh hasil laporan lembaga internasional mengenai masalah pendidikan, indeks pendidikan Indonesia berada pada urutan ke 110 dari 180 negara di dunia. Selain itu, hasil studi TIMMS Tahun 2011 menunjukkan bahwa prestasi sains siswa Indonesia berada di urutan ke-40 dengan skor 406 dari 42 
negara peserta (Napitupulu, 2012). Hasil studi PISA Tahun 2012 menunjukkan bahwa kemampuan literasi sains siswa Indonesia masih sangat rendah, terbukti dengan skor literasi sains 382 dan menempati peringkat 64 dari 65 negara peserta (Nurfuadah, 2013). Salah satu penyebab rendahnya prestasi siswa ini adalah lemahnya proses pembelajaran di Indonesia. Siswa kurang didorong untuk mengembangkan kemampuan berpikir tingkat tingginya.

Higher Order Thinking Skills (HOTS) didefinisikan sebagai penggunaan pikiran secara lebih luas untuk menemukan tantangan baru. HOTS ini menghendaki seseorang untuk menerapkan informasi baru atau pengetahuan sebelumnya dan memanipulasi informasi untuk menjangkau kemungkinan jawaban dalam situasi baru (Heong, dkk, 2011). HOTS diperlukan agar seseorang mampu menghadapi masalah yang menuntut pemikiran dan pemecahan masalah tingkat tinggi. Oleh karena itu, calon guru harus memiliki HOTS untuk menghadapi tantangan era MEA. Dalam suatu proses pembelajaran Matematika, jika seorang mahasiswa menggunakan keterampilan berpikir tingkat tingginya maka pembelajaran tersebut akan menjadi pembelajaran yang bermakna.

Hasil observasi awal peneliti menunjukkan HOTS mahasiswa PGSD Universitas PGRI Adi Buana Surabaya tergolong rendah. Hasil belajar Matematika mahasiswa, rata-ratanya 42,5 dengan nilai tertinggi 40 dan nilai terendah 22. Hal ini diduga karena pembelajaran tidak memberikan keleluasaan kepada mahasiswa untuk memberdayakan potensi otak secara optimal, dimana pembelajaran pada umumnya lebih menekan pada penggunaan fungsi otak kiri. Sementara itu, mengajarkan HOTS perlu didukung oleh pergerakan otak kanan. Karakteristik ini dapat dijumpai dalam pembelajaran Brain-based Learning (BbL) menawarkan suatu konsep pembelajaran yang diselaraskan dengan cara kerja otak yang didesain secara alamiah untuk belajar.

Penelitian yang dilakukan oleh Ozden \& Gultekin (2008) menunjukkan bahwa pembelajaran BBL terbukti lebih efektif dibandingkan pembelajaran konvensional pada pelajaran IPA dalam hal meningkatkan hasil belajar siswa serta daya ingatan siswa terhadap pengetahuan yang telah didapat. Hasil penelitian Riska Saparina (2015) menunjukkan bahwa pembelajaran BBL berpengaruh nyata terhadap hasil belajar siswa baik pada ranah kognitif, afektif, maupun 


\section{Via Yustitia1, Triman Juniarso ${ }^{2}$}

psikomotorik. Hasil penelitian Danisa (2015) juga menunjukkan bahwa modul pembelajaran biologi berbasis $\mathrm{BbL}$ efektif dalam meningkatkan keterampilan proses sains dan kemampuan pengaturan diri.

BBL adalah pembelajaran yang berpusat pada siswa dan guru sebagai fasilitator yang berperan mendukung kognitif siswa (Awolola, 2011). Ciri pembelajaran $\mathrm{BbL}$ adalah kelas yang rileks, pembelajaran yang konstruktivistik, menekankan aspek kerjasama antar siswa, adanya cukup waktu bagi siswa untuk merefleksikan materi yang telah diterimanya, pembelajaran yang bermakna dan kontekstual. Hal ini sejalan dengan pendapat Bowen (2011) bahwa model BBL dapat menciptakan belajar bermakna bagi siswa karena mampu mengubah fisiologi otak siswa ketika siswa berkolaborasi dalam pembelajaran dan berinteraksi. Berdasarkan pemaparan di atas, penulis tertarik untuk melakukan penelitian tentang "Keefektifan Brain Based Learning terhadap Higher Order Thinking Skills mahasiwa PGSD pada mata kuliah Konsep Matematika Lanjut”.

\section{METODE PENELITIAN}

Jenis penelitian yang digunakan dalam penelitian ini adalah penelitian eksperimen. Desain penelitian eksperimen ini menggunakan bentuk true experimental design tipe posttest only control (Sugiono, 2008). Populasi dalam penelitianini adalah mahasiswa PGSD Universitas PGRI Adi Buana Surabaya angkatan 2017. Variabel yang akan diukur dalam penelitian ini adalah HOTS. Teknik pengambilan sampel menggunakan teknik simple random sampling. Sampel dalam penelitian ini adalah kelas 2017 A sebagai kelas eksperimen yang diajar menggunakan model pembelajaran BBL dan kelas 2017 B sebagai kelas kontrolyang diajar menggunakan model pembelajaran klasikal. Instrumen yang digunakan untuk pengumpulan data adalah tes HOTS, lembar observasi keterlaksanaan pembelajaran dan aktivitas mahasiswa, dan angket respon mahasiswa terhadap pembelajaran BBL. Teknik pengambilan data dalam penelitian ini menggunakan metode dokumentasi, tes, observasi, dan angket. Analisis data awal meliputi uji normalitas dan homogenitas populasi, uji kesamaan rata-rata (uji dua pihak). Analisis data akhir meliputi uji normalitas dan 
uji homogenitas kelas sampel, uji ketuntasan belajar (uji t dan uji proporsi pihak kiri), dan uji kesamaan rata-rata pihak kanan.

\section{HASIL DAN PEMBAHASAN}

Berdasarkan analisis data awal, diketahui bahwa populasi berdistribusi normal dan memiliki varians yang homogen. Hasil uji kesamaan rata-rata menunjukkan bahwa kedua sampel memiliki kemampuan awal yang sama. Analisis data akhir dilakukan setelah diperoleh nilai HOTS mahasiswa pada mata kuliah Konsep Matematika Lanjut. Hasil analisis deskriptif data akhir dapat dilihat pada Tabel 1 berikut ini.

Tabel 1. Hasil Analisis Deskriptif Data Akhir

\begin{tabular}{lcccccc}
\hline \multicolumn{1}{c}{ Kelas } & N & $\begin{array}{c}\text { Nilai } \\
\text { Tertinggi }\end{array}$ & $\begin{array}{c}\text { Nilai } \\
\text { Terendah }\end{array}$ & Rata-rata & Varian & $\begin{array}{c}\text { Standar } \\
\text { Deviasi }\end{array}$ \\
\hline Eksperimen & 40 & 98 & 68 & 84,13 & 87,55 & 9,36 \\
Kontrol & 40 & 92 & 62 & 78,93 & 49,97 & 7,07 \\
\hline
\end{tabular}

Berdasarkan hasil perhitungan uji normalitas data akhir kelas sampel diperoleh $\chi_{\text {hitung }}^{2}=10,27$ dan $\chi_{\text {tabel }}^{2}=11,1$ dengan taraf nyata $\alpha=5 \%, \mathrm{dk}=\mathrm{k}-$ $3=10-3=7$. Karena $\chi_{\text {hitung }}^{2}<\chi_{\text {tabel }}^{2}$ maka $\mathrm{H}_{0}$ diterima, artinya data akhir kelas sampel berdistribusi normal. Hasil uji normalitas akan berpengaruh terhadap uji hipotesis yang digunakan, statistik parametrik atau statistik non parametrik.

Berdasarkan hasil perhitungan uji homogenitas, diperoleh $\mathrm{F}_{\text {hitung }}=1,75$ dan $\mathrm{F}_{\text {tabel }}=1,89$ dengan taraf nyata $\alpha=5 \%$, dk pembilang $=n_{1}-1=$ $40-1=39, \mathrm{dk}$ penyebut $=n_{2}-1=40-1=39$. Karena $\mathrm{F}_{\text {hitung }}<\mathrm{F}_{\text {tabel }}$ maka $\mathrm{H}_{0}$ diterima, artinya kelas sampel memiliki varians homogen. Jika data mempunyai varians yang sama maka kelompok tersebut dikatakan homogen.

Dalam penelitian ini uji ketuntasan belajar dalam penelitian ini meliputi ketuntasan secara individual dan ketuntasan secara klasikal. Ketuntasan secara individual digunakan untuk mengetahui pembelajaran yang dilakukan dapat mencapai KKM yang sudah ditetapkan, yaitu 76. Ketuntasan secara klasikal digunakan untuk mengukur keberhasilan kelas dilihat dari sekurang-kurangnya $75 \%$ dari jumlah mahasiswa yang ada di kelas tersebut telah tuntas belajar. 
Berdasarkan perhitungan uji ketuntasan individual menggunakan uji t satu pihak (uji pihak kiri) menunjukkan bahwa data akhir pada kelas yang diajar menggunakan model BBL dan kelas yang diajar menggunakan model klasikal mencapai KKM individual. Hasil uji ketuntasan individual kelas sampel dapat dilihat pada Tabel 2 berikut ini.

Tabel 2. Hasil Uji Ketuntasan Individual Kelas Sampel

\begin{tabular}{ccccccc}
\hline Kelas & $\mathbf{N}$ & Rata-rata & $\boldsymbol{\mu}_{\mathbf{0}}$ & $\boldsymbol{t}_{\text {hitung }}$ & $-\boldsymbol{t}_{\text {tabel }}$ & Kriteria \\
\hline Eksperimen & 40 & 84,13 & 76 & 5,49 & $-1,68$ & $\mathrm{H}_{\mathrm{o}}$ diterima \\
Kontrol & 40 & 78,93 & 76 & 2,62 & $-1,68$ & $\mathrm{H}_{0}$ diterima \\
\hline
\end{tabular}

Berdasarkan perhitungan uji klasikal menggunakan uji proporsi satu pihak (uji pihak kiri) menunjukkan bahwa data akhir pada kelas sampel mencapai KKM individual. Hasil uji ketuntasan klasikal kelas sampel dapat dilihat pada Tabel 3 berikut ini.

Tabel 3. Hasil Uji Ketuntasan Klasikal Kelas Sampel

\begin{tabular}{ccccccc}
\hline Kelas & $\sum$ tuntas & $\mathbf{N}$ & $\begin{array}{c}\text { Persentase } \\
\text { Ketuntasan } \\
(\boldsymbol{\pi})\end{array}$ & $\mathbf{z}_{\text {hitung }}-\mathbf{z}_{\text {tabel }}$ & Kriteria \\
\hline Eksperimen & 35 & 40 & $88 \%$ & 1,90 & $-1,64$ & $\mathrm{H}_{\mathrm{o}}$ diterima \\
Kontrol & 31 & 40 & $78 \%$ & 0,44 & $-1,64$ & $\mathrm{H}_{\mathrm{o}}$ diterima \\
\hline
\end{tabular}

Penilaian terhadap keterlaksanaan pembelajaran dilakukan pada setiap kegiatan pembelajaran berlangsung yaitu pada kelas eksperimen dengan model BBL dan pada kelas kontrol dengan model pembelajaran klasikal. Penilaian ini bertujuan untuk mengetahui seberapa besar kemampuan peneliti yang bertindak sebagai guru dalam mengelola kelas ketika mengajar. Penilaian diserahkan kepada observer yaitu dosen PGSD Universitas PGRI Adi Buana Surabaya. Hasil analisis observasi keterlaksanaan pembelajaran dapat dilihat pada Tabel 4 berikut ini.

Tabel 4. Hasil Analisis Observasi Keterlaksanaan Pembelajaran

\begin{tabular}{ccccccc}
\hline \multirow{2}{*}{$\begin{array}{c}\text { Pertemuan } \\
\text { ke- }\end{array}$} & $\begin{array}{c}\text { Kelas } \\
\text { Eksperimen }\end{array}$ & Kriteria & Kelas Kontrol & Kriteria \\
\cline { 2 - 7 } & Skor & $\%$ & & Skor & $\%$ & \\
\hline 1 & 33 & 68,7 & Baik & 36 & 63,3 & Baik \\
2 & 36 & 75 & Baik & 42 & 70 & Baik \\
\hline
\end{tabular}




\begin{tabular}{ccccccc}
\hline \multirow{2}{*}{$\begin{array}{c}\text { Pertemuan } \\
\text { ke- }\end{array}$} & $\begin{array}{c}\text { Kelas } \\
\text { Eksperimen }\end{array}$ & Kriteria & Kelas Kontrol & Kriteria \\
\cline { 2 - 7 } & Skor & $\%$ & & Skor & $\%$ & \\
\hline 3 & 39 & 81,25 & Sangat baik & 46 & 76,6 & Sangat baik \\
4 & 40 & 83,3 & Sangat baik & 48 & 80 & Sangat baik \\
5 & 42 & 87,5 & Sangat Baik & 51 & 85 & Sangat baik \\
6 & 45 & 93,7 & Sangat Baik & 53 & 88,3 & Sangat baik \\
Rata-rata & & 81,6 & Sangat Baik & & 76,6 & Sangat baik \\
\hline
\end{tabular}

Penilaian aktivitas mahasiswa dilakukan setiap kegiatan pembelajaran berlangsung yaitu pada kelas eksperimen yang diajar dengan model BBL dan kelas kontrol dengan model klasikal. Penilaian ini bertujuan untuk mengetahui seberapa besar aktivitas mahasiswa dalam mengikuti kegiatan pembelajaran. Penilaian diserahkan kepada observer, yaitu dosen PGSD Universitas PGRI Adi Buana Surabaya. Hasil penilaian aktivitas mahasiswa dalam kegiatan pembelajaran di kelas eksperimen dan kelas kontrol dapat dilihat pada Tabel 5 berikut ini.

Tabel 5. Hasil Analisis Aktivitas Mahasiswa

\begin{tabular}{ccccccc}
\hline \multirow{2}{*}{$\begin{array}{c}\text { Pertemuan } \\
\text { ke- }\end{array}$} & $\begin{array}{c}\text { Kelas } \\
\text { Eksperimen }\end{array}$ & Kriteria & Kelas Kontrol & Kriteria \\
\cline { 2 - 7 } & Skor & $\%$ & & Skor & $\%$ & \\
\hline 1 & 34 & 65,3 & Baik & 33 & 63,4 & Baik \\
2 & 40 & 76,9 & Baik & 35 & 67,3 & Baik \\
3 & 43 & 82 & Sangat Baik & 38 & 73,1 & Baik \\
4 & 45 & 86,5 & Sangat Baik & 40 & 76,9 & Sangat Baik \\
5 & 47 & 90,3 & Sangat Baik & 42 & 80,8 & Sangat Baik \\
6 & 49 & 94,2 & Sangat Baik & 44 & 84,6 & Sangat Baik \\
Rata-rata & & 82,6 & Sangat Baik & & 74,3 & Baik \\
\hline
\end{tabular}

Berdasarkan Tabel 5, aktivitas mahasiswa yang diajar menggunakan model BBL dalam kategori sangat baik. Pembelajaran pada kelas eksperimen menerapkan model BBL. Mahasiswa antusias dalam mengikuti pembelajaran 
dengan tingkat keaktifan yang sangat baik. Dalam proses pembelajaran BBL terdapat tahapan belajar kelompok yang memberikan kesempatan kepada mahasiswa untuk saling bertukar pendapat atau ide untuk memecahkan masalah. Hal ini sesuai dengan teori belajar Vygotsky dan Piaget, sebagaimana yang dikutip oleh Trianto (2014), yaitu interaksi sosial mahasiswa diperlukan dalam membangun pengalaman-pengalaman dan pengetahuan-pengetahuan baru menjadi lebih bermakna. Pembelajaran BBL mampu membuat mahasiswa lebih tertarik dan tidak merasa bosan belajar matematika. Mahasiswa saling berdiskusi dan dapat membantu mahasiswa yang memiliki kesulitan belajar untuk mencapai suatu tingkat pemahaman tentang materi pelajaran. Mahasiswa saling bekerjasama untuk menjadikan semua anggota timnya mendapatkan prestasi yang lebih baik. Pada kelas eksperimen yang dikenai pembelajaran BBL, mahasiswa cenderung lebih siap mengikuti kegiatan pembelajaran dengan mempelajari terlebih dahulu materi yang akan dibahas.

Uji kesamaan rata-rata digunakan untuk mengetahui mana yang lebih baik antara kelas yang diajar dengan model pembelajaran BBL dan kelas yang diajar dengan model pembelajaran klasikal. Berdasarkan perhitungan uji kesamaan ratarata satu pihak (uji pihak kanan) diperoleh $t_{\text {hitung }}=2,805$ dan $t_{\text {tabel }}=1,665$. Karena $t_{\text {hitung }}>t_{\text {tabel }}$ maka $\mathrm{H}_{0}$ ditolak, artinya rata-rata HOTS mahasiswa kelas eksperimen lebih baik dari pada kelas kontrol. Pada pembelajaran BBL menciptakan suasana rileks, pembelajaran yang konstruktivistik, mahasiswa diberi kebebsan mengkonstruksi pemahamannya sendiri, dan menekankan aspek kerjasama antar mahasiswa. Hal ini sejalan dengan pendapat Bowen (2011) bahwa model BBL dapat menciptakan belajar bermakna bagi siswa karena mampu mengubah fisiologi otak siswa ketika siswa berkolaborasi dalam pembelajaran dan berinteraksi. Hal ini juga sejalan dengan hasil penelitian yang dilakukan oleh Ozden \& Gultekin (2008) menunjukkan bahwa pembelajaran BBL terbukti lebih efektif dibandingkan pembelajaran konvensional pada pelajaran IPA dalam hal meningkatkan hasil belajar siswa serta daya ingatan siswa terhadap pengetahuan yang telah didapat. 


\section{SIMPULAN}

Hasil penelitian menunjukkan bahwa: (1) rata-rata HOTS mahasiswa yang diajar menggunakan model BBL mencapai KKM individual dan klasikal; (2) ratarata HOTS mahasiswa yang diajar menggunakan model BBL lebih baik daripada mahasiswa yang diajar menggunakan model pembelajaran klasikal. (3) keterlaksanaan pembelajaran pada kelas eksperimen yang diajar menggunakan model BBL dalam kategori sangat baik; (4) aktivitas mahasiswa pada kelas eksperimen yang diajar menggunakan model BBL dalam kategori sangat baik. Oleh karena itu, dapat disimpulkan bahwa model pembelajaran BBL efektif terhadap HOTS mahasiswa PGSD pada mata kuliah Konsep Matematika Lanjut.

\section{DAFTAR PUSTAKA}

Alpusari, M. (2014). Upaya Meningkatkan Aktivitas dan Hasil Belajar Mahasiswa Melalui Penerapan Model Pembelajaran Inkuiri. Journal Primary PGSD FKIP Universitas Riau, 3(1), 23-31.

Awolola, S. A. (2011). Cypriot Journal of Educational Science: Effectif brain based learning strategy on student's achievement in senior secondary school mathematics in Oyo State, Nigeria. Pdf. (Online), (www.worldeducation-center.org/index.php/cjes). Diakses 25 Oktober 2012.

Budiyono. (2009). Statistika Untuk Penelitian. Surakarta: UNS Press.

Bowen, C. H. (2011). Resolving the Conflict: Brain-Based Learning, Best Practices, and No Child Left Behind Resolving the Conflict: Brain-Based Learning, Best Practices, and No Child Left Behind. Perspectives in Learning: A Journal of the College of Education \& Health Professions Columbus State University, 12(1).

Danisa. (2014). Pengembangan Modul Pembelajaran Biologi berbasis Brain Based Learning. Prosiding Seminar Nasional Pendidikan Biologi UNS.

Given, B. K. (2007). Brain-based Teaching. (L. H. Dharma, Penerj.) Bandung: Kaifa.

Heong, Y. M., Othman, W. D., Md Yunos, J., Kiong, T. T., Hassan, R., \& Mohamad, M. M. (2011). The Level of Marzano Higher Order Thinking Skills Among Technical Education Students. International Journal of Social and Humanity, 1(2), 121-125.

Jensen, E. (2008). Brain-Based Learning. Yogyakarta: Pustaka Pelajar.

King, JF; Goodson, Ludwika, dan Rohani, Faranak. 2010. Higher Order Thinking

Skills, Definition, Teaching Strategis, Assesment. A Publication of The

Educational Services Program. Tersedia di www.Cala.fsu.edu

Napitupulu, E. L. (2012). Prestasi Sains dan Matematika IndonesiaMenurun. Diperoleh 6 Januari 2013, dari:http://kompas.com.

Nurfuadah, R. N. (2013). Miris, Indeks Kepintaran Anak Indonesia Jeblok!. Diperoleh 6 Januari 2013, dari: http://okezone.com. 
Ozden, M. \& Gultekin, M. (2008). The effects of BBL on academic achievements and retention of knowladge in science course. EJSE, 12(1).

Saparina, R. (2015). Pengaruh Model Brain Based Learning (Bbl) Terhadap Hasil Belajar Biologi Siswa Kelas X SMA Negeri Colomadu Tahun Pelajaran 2012/2013. Journal Bio Pedagogi, 4(1), 59-65.

Sugiyono. (2010). Metode Penelitian Kuantitatif, Kualitatif dan R\&D. Bandung: Alfabeta.

Suyitno, A. (2004). Dasar-Dasar dan Proses Pembelajaran Matematika I. Semarang: UNNES.

Tiurlina. (2007). Pemahaman Konsep Dasar Matematika SD pada Mahasiswa D2 PGSD UPI Kampus Serang. Journal Pendidikan Dasar, 5(7), 1-4.

Trianto. (2014). Model-Model Pembelajaran Inovatif Berorientasi Konstruktivistik. Surabaya: Prestasi Pustaka.

Tüfekçi, S., Demirel, M. (2009). The Effect of Brain Based Learning on Achievement, Retention, Attitude and Learning Process. Procedia Social and Behavioral Sciences. 1(1), 1782-1791.

Wardana, N. 2010. Pengaruh Model Pembelajaran Berbasis Masalah Terhadap Kemampuan Berpikir Tingkat Tinggi dan Pemahaman Konsep Fisika. $\begin{array}{lllll}\text { Diperoleh } & 28 & \text { Januari } & 2014 & \text { dari }\end{array}$ http://jurnal.pdii.lipi.go.id/admin/jurnal/621016251635.858-4543.pdf. 